\title{
Attitudes About the Economic Impact of the COVID-19 Lockdown in the Republic of Croatia on Micro, Small and Medium Enterprises
}

\author{
Ivana Sataic \\ Independent Researcher, Polica znanja Ltd., Zagreb, Croatia \\ ivana.sataic@gmail.com
}

\section{ABSTRACT}

SARS-CoV-2 is a novel virus in the coronavirus family that affect humans which causes COVID-19 disease. It was first detected in the town Wuhan in China at the end of 2019 and later spread all over the world. The first COVID-19 case in Croatia was detected on February 25th, 2020. Less than a month later, on March 16th, 2020, the Government of the Republic of Croatia declared a lockdown due to the rapid spread of SARS-CoV-2 virus in Europe, especially in the neighbouring Italy, as well as the increase of the number of patients in the Republic of Croatia. During the lockdown all business activities, except grocery stores, were closed and the economy slowed. On March 17th, 2020, the Government announced relief measures to support the economy in coping with COVID-19 epidemic, that include interventional procurement of critically important medical and sanitary equipment, delays in tax payments, purchasing of surpluses of potentially threatened business such as agricultural or industrial goods, measures to support tourism activities, as well as rationalization of public spending without measures for healthcare and social services. From April 27th to May 11th, 2020 the social and economic activity gradually started again. This research discusses how Croatian SMEs have been affected by the COVID-19 epidemic lockdown and answers some of the most important questions about the resilience of Croatian SMEs during the COVID-19 outbreak.

Keywords: Economic Measures, Economic Support, Lockdown, SAR-CoV-2, SMEs

Cite this article as: Sataic, I. (2021). Attitudes About the Economic Impact of the COVID19 Lockdown in the Republic of Croatia on Micro, Small and Medium Enterprises. European Journal of Economics, 1(1), 22-33. https://doi.org/10.33422/eje.v1i1.44

\section{Introduction}

SARS-CoV-2, a novel coronavirus and pathogen of COVID-19 disease that affects humans, originates from Wuhan in China and has spread all over the world. In addition to presenting a global health problem, COVID-19 disease is having major consequences on national and global economy. According to Bobdey \& Ray (2020) experts have predicted that COVID-19 will lower global gross domestic product growth by one-half of a percentage point for 2020 (from $2,9 \%$ to $2,4 \%$ ) while the whole world is now a single global community, where any major happening in one part is bound to have repercussions in the rest of the world.

To control the spread of COVID-19 disease, on March 16th, 2020 the Government of the Republic of Croatia declared a lockdown which affected almost all sectors and industries, especially SMEs. The consequences for the Croatian economy will be greater the longer the virus spreads, so SMEs are expressing concerns for financial stability and the future of their business. To mitigate and minimize the consequences of the COVID-19 epidemic, which has been declared a global pandemic, a strong and coordinated response by the Government of the Republic of Croatia is needed. The spread of the virus has raised many questions about the 
border closure and lockdown as effective measures to prevent the spread of disease all over Croatia. For 54 days Croatia adjusted its border management policy to the new conditions caused by the epidemic. Now, mitigated anti-epidemic measures are still being applied. Without questioning the effectiveness of epidemiological measures, the most frequently asked question is what consequences the COVID-19 epidemic will have on SMEs in Croatia. For the reasons above, the aim of this paper is to examine the impact of the SARS-CoV-2 spreading and the Government's relief measures during the lockdown, as well as the importance of recognizing and applying change management during the crisis caused by the COVID-19 disease.

\subsection{Literature Overview}

Small and medium-sized enterprises (SMEs) are considered the backbone of the economy in both developed and transition countries. According to the European Commission (2003), there are three broad parameters to define SMEs: a) micro-enterprises with up to 10 employees, b) small enterprises with up to 50 employees, c) medium-sized enterprises with up to 250 employees; so SMEs comprise the category of micro, small and medium-sized enterprises which employ less than 250 employees and have an annual turnover not exceeding 50 million euro, and/or an annual balance sheet total not exceeding 43 million euro. Recent research presented by the OECD (2019) shows that SMEs are an essential driver of economic and social well-being by representing $99 \%$ of all business, generating nearly $60 \%$ of employment and totaling between $50 \%$ and $60 \%$ of value added in the OECD area. That proves SMEs are of key importance for sustainable and inclusive economic growth and a tool to ensure needed reforms and transformation for successful economic development in future. In view of the above, especially in the COVID-19 epidemic conditions, this segment of the economy should be approached with special attention and strong measures that will ensure its survival and growth in uncertain future.

As the COVID-19 epidemic was proclaimed pandemic and affected global economy, recent researches showed that GDP growth would take a hit ranging from $3 \%$ to $6 \%$ depending on the country. In other scenarios, GDP can fall more than $10 \%$, in some countries even more than $15 \%$. Service-orientated economies will be specially negatively affected and have more jobs at risk (Fernandes, 2020). According to Atkeson (2020), even putting aside concerns about public health, it appears that there is a significant economic tradeoff related to social distancing, the economic costs of strong social distancing measures imposed for an entire 12-18 months on the one hand or the economic costs of a large cumulative burden of lost work time (and life) due to the disease. Which option would have the more severe economic consequences is hard to determine. McKibbin \& Fernando (2020) consider that in the case where COVID-19 develops into a global pandemic, the impact on the economy can escalate quickly so a range of policy responses will be required in both, the short term and the long term in the coming years. Baldwin \& Tomiura (2020) underline that there is a danger of permanent danger to the trade system driven by policy and firm's reactions. The combination of the US' ongoing trade war against its trading partners, especially China, and the supply-chain distruptions that are likely to be caused by COVID-19, the pandemic could lead to a push to repatriate supply chains. In these new conditions, SMEs should quickly respond to any change in their business environment. Change management is the complex question for each enterprise as it is the process of enterprises ' transition from an existing to a new state. Garcia-Cabrera \& Garcia Barba Hernandez (2012) consider that enterprises should change and adapt to their environment to survive and grow. Accordingly, in COVID-19 epidemic conditions, SMEs changes could be successful only if enterprises communicate with their business environment. 


\section{Research Methodology}

\subsection{Objectives and Methods of Research}

The main purpose of this study is to examine the attitudes of Croatian micro, small and medium entrepreneurs about the economic impact of COVID-19 epidemic during the lockdown period in Croatia and importance of change management for the future of their business. The following research objectives were identified: 1 . financial and other business problems during the epidemic, 2. current cash flow and cash flow deficit settlement, 3. fulfillment of contractual obligations, 4. the effectiveness of the Government's measures to save the economy, 5. total revenue expectations, 6 . the importance of change management during and after the crises due to COVID-19 epidemic. The data for this empirical research was collected using the survey initiated by the Alliance of Enterprise Survey for Innovation and Entrepreneurship in China led by Peking University, which was adapted to Croatian SMEs specificities by the author. Multiple-choice questionnaire with the choice of maximum two possible answers was designed to examine entrepreneurs' attitudes about the economic impact of the COVID-19 epidemic on SMEs in Croatia. The part of the questionnaire related to change management was designed by the author as a one-choice questionnaire with five possible answers to each question, ranging from strongly agree to strongly disagree on a Likert scale, to explore entrepreneurs' attitudes of change management importance during and after the COVID-19 crisis. The questionnaire also included demographic characteristics, such as gender, age, education level, size of the enterprise, main enterprise's activity, and the county in which the enterprise has registered its office. After being publicly available and filled, its comprehensiveness was checked and validated.

\subsection{Analysis and Results}

During the COVID-19 lockdown period in Croatia, 105 respondents took part in this survey. IBM SPSS Statistics for Windows, version 20.0 was used for the statistical analysis. The processing of collected data was done by summary statistics with frequencies and percent, to describe the respondent's answers and confirmed by F-tests. All tests were two-sided and $p$ values less than 0,05 were considered statistically significant.

\subsubsection{Baseline Demographics}

One hundred and five answers were collected by the questionnaire publicly available on the Internet. Fifty-seven respondents (54\%) were male, while forty-eight respondents (46\%) were female. Five respondents $(4,7 \%)$ were $18-29$ years old, thirty-two respondents $(30,5 \%)$ were 30-39 years old, thirty respondents $(28,6 \%)$ were $40-49$ years old, twenty-four respondents $(22,9 \%)$ were $50-59$ years old and fourteen respondents $(13,3 \%)$ were $60-69$ years old. According to the data of Population Census in the Republic of Croatia in 2011, the respondents were matched by age and gender. In thirty-five respondents $(33,3 \%)$ the highest educational level was a high school. Twelve respondents $(11,4 \%)$ finished a college, 49 respondents $(46,7 \%)$ finished university studies, while nine respondents $(8,6 \%)$ had a Master of Science (MSc) or Doctor of Science (PhD) degree. Seventy-eight enterprises $(74,3 \%)$ of all included in the research were micro enterprises, twenty-one enterprises $(20 \%)$ were small enterprises and six enterprises $(5,7 \%)$ were medium-sized enterprises. Observed by counties (there are 21 counties in the Republic of Croatia) the most respondents were from the City of Zagreb (39\%), which is also the capital of the Republic of Croatia, then from the Zagreb County $(11,4 \%)$, Split-Dalmatia County $(9,5 \%)$ and then the rest of the counties. The enterprises were classified according to the national classification of activities (NKD) which structurally corresponded to NACE Rev. 2. The most respondents worked in the tourism sector $(10,5 \%)$, restaurants and 
hospitality management $(9,5 \%)$, accounting and bookkeeping services $(8,6 \%)$ and then in all other business activities classified, as mentioned before.

\subsubsection{Business status and needs of entrepreneurs}

Out of a total of 105 enterprises that participated in this survey, 102 enterprises $(97,1 \%)$ were active, while 3 enterprises (2,9\%) were not active after February 25, 2020, the day when the first case of COVID-19 disease was confirmed in Croatia. One respondent $(33,3 \%)$ of inactive enterprises stated that it would take more than 3 moths for their enterprise to recover, while two respondents $(66,7 \%)$ could not estimate the period in which they expected their enterprise would recover and return to the market.

\subsubsection{Financial and other Business Problems}

All respondents estimated the most significant financial problems for their enterprises during the lockdown due to the COVID-19 epidemic. Factors with highest frequency and highest valid percent were considered most significant: No specific problems (frequency 17, valid percent 16,2); Staff wages and social security charges and Payment of invoices (frequency 15, valid percent 14,3); Rent and Payment of invoices (frequency 12, valid percent 11,4). Cumulatively, $41,9 \%$ of the entrepreneurs who participated in the study most often face the problems presented in the Table 1 . Additionally, a two-sided F test $(\mathrm{p}=0,000)$ demonstrated all the above statements to be statistically significant and appear equally important in respondents assessing financial problems during the COVID-19 outbreak.

Table 1.

The most significant financial problems during the COVID-19 epidemic outbreak.

\begin{tabular}{lcccc}
\hline & Frequency & Percent & $\begin{array}{c}\text { Valid } \\
\text { Percent }\end{array}$ & $\begin{array}{c}\text { Cumulative } \\
\text { Percent }\end{array}$ \\
\hline No specific problems & 17 & 16,2 & 16,2 & 16,2 \\
Staff wages and social security charges; Repayment of & 8 & 7,6 & 7,6 & 23,8 \\
$\quad$ loans & 12 & 11,4 & 11,4 & 35,2 \\
Rent; Payment of invoices & 9 & 8,6 & 8,6 & 43,8 \\
Staff wages and social security charges & 6 & 5,7 & 5,7 & 49,5 \\
Staff wages and social security charges; Rent & 2 & 1,9 & 1,9 & 51,4 \\
Repayment of loans & 15 & 14,3 & 14,3 & 65,7 \\
Staff wages and social security charges; Payment of & & 2,9 & 2,9 & 68,6 \\
$\quad$ invoices & 3 & 2,9 & 2,9 & 71,4 \\
Staff wages and social security charges; Other expenses & 3 & 3,8 & 3,8 & 75,2 \\
Repayment of loans; Other expenses & 4 & 2,9 & 78,1 \\
Rent; Repayment of loans & 3 & 2,9 & 6,7 & 84,8 \\
Rent; Other expenses & 7 & 6,7 & 1,0 & 85,7 \\
Other expenses & 1 & 1,0 & 5,7 & 91,4 \\
Rent & 6 & 5,7 & 6,7 \\
Repayment of loans; Payment of invoices & 7 & 6,7 & 6,7 & 100,0 \\
Payment of invoices; Other expenses & 2 & 1,9 & 1,9 & 100 \\
Payment of invoices & 105 & 100 & & \\
Total & & & & \\
\hline
\end{tabular}

Source. author's calculation

Beside the most significant financial problems, entrepreneurs who took part in this study also named other business problems that their enterprises had dealt with during the COVID-19 epidemic. The factors with the highest frequency and highest valid percent were considered as the most significant: Reduction of orders (frequency 16, valid percent 15,2); Reduction of orders and Disruption of logistics (frequency 13, valid percent 12,4); Reduction of orders and Increased difficulty of financing (frequency 12, valid percent 11,4); Reduction of orders and Inability to deliver existing orders (frequency 10, valid percent 9,5). Cumulatively, $48,5 \%$ of 
the entrepreneurs who participated in the survey most often face the problems presented in the Table 2. A two-sided F test $(\mathrm{p}=0,000)$ demonstrated all the above statements to be statistically significant and appear equally important in respondents assessing financial problems during the COVID-19 outbreak.

Table 2.

Other business problems during the COVID-19 epidemic outbreak.

\begin{tabular}{|c|c|c|c|c|}
\hline & Frequency & Percent & Valid Percent & $\begin{array}{c}\text { Cumulative } \\
\text { Percent }\end{array}$ \\
\hline $\begin{array}{l}\text { Increased difficulty of financing; Disruption of } \\
\text { logistics }\end{array}$ & 2 & 1,9 & 1,9 & 1,9 \\
\hline $\begin{array}{l}\text { Reduction of orders; Inability to deliver existing } \\
\text { orders }\end{array}$ & 10 & 9,5 & 9,5 & 11,4 \\
\hline $\begin{array}{l}\text { Reduction of orders; Increased difficulty of } \\
\text { financing }\end{array}$ & 12 & 11,4 & 11,4 & 22,9 \\
\hline Reduction of orders & 16 & 15,2 & 15,2 & 38,1 \\
\hline Other & 8 & 7,6 & 7,6 & 45,7 \\
\hline Reduction of orders; Disruption of logistics & 13 & 12,4 & 12,4 & 58,1 \\
\hline $\begin{array}{l}\text { Staff wages and social security charges; Payment } \\
\text { of invoices }\end{array}$ & 3 & 2,9 & 2,9 & 61,0 \\
\hline $\begin{array}{l}\text { Reduction of orders; Upstream and downstream } \\
\text { chain disruptions }\end{array}$ & 5 & 4,8 & 4,8 & 65,7 \\
\hline $\begin{array}{l}\text { Inability to deliver existing orders; Increased } \\
\text { difficulty of financing }\end{array}$ & 1 & 1,0 & 1,0 & 66,7 \\
\hline $\begin{array}{l}\text { Reduction of orders; Existing loans cannot be } \\
\text { extended }\end{array}$ & 2 & 1,9 & 1,9 & 68,6 \\
\hline $\begin{array}{l}\text { Reduction of orders; Insufficient protective } \\
\text { equipment (e.g., masks) }\end{array}$ & 2 & 1,9 & 1,9 & 70,5 \\
\hline $\begin{array}{l}\text { Inability to deliver existing orders; Insufficient } \\
\text { protective equipment (e.g., masks) }\end{array}$ & 1 & 1,0 & 1,0 & 71,4 \\
\hline Disruption of logistics & 2 & 1,9 & 1,9 & 73,3 \\
\hline $\begin{array}{l}\text { Disruption of logistics; Upstream and downstream } \\
\text { chain disruptions }\end{array}$ & 5 & 4,8 & 4,8 & 78,1 \\
\hline Reduction of orders; Other & 3 & 2,9 & 2,9 & 81,0 \\
\hline We have no other business problems & 6 & 5,7 & 5,7 & 86,7 \\
\hline Increased difficulty of financing & 3 & 2,9 & 2,9 & 89,5 \\
\hline Increased difficulty of financing; Ot,her & 1 & 1,0 & 1,0 & 90,5 \\
\hline Disruption of logistics; Other & 5 & 4,8 & 4,8 & 95,2 \\
\hline $\begin{array}{l}\text { Disruption of logistics; Insufficient protective } \\
\text { equipment (e.g., masks) }\end{array}$ & 2 & 1,9 & 1,9 & 97,1 \\
\hline $\begin{array}{l}\text { Increased difficulty of financing; Existing loans } \\
\text { cannot be extended }\end{array}$ & 1 & 1,0 & 1,0 & 98,1 \\
\hline $\begin{array}{l}\text { Disruption of logistics; We have no other business } \\
\text { problems }\end{array}$ & 1 & 1,0 & 1,0 & 99,0 \\
\hline $\begin{array}{l}\text { Increased difficulty of financing; Insufficient } \\
\text { protective equipment (e.g., masks) }\end{array}$ & 1 & 1,0 & 1,0 & 100,0 \\
\hline Total & 105 & 100 & 100 & \\
\hline
\end{tabular}

Source. author's calculation

\subsubsection{Cash Flow}

Cash flow is in accounting practice considered as the amount of money that circulates through the enterprise in a given period. It is the sum of enterprises' new borrowings and earned cash from issued shares, as well as cash receipts from customers and amortization. For this study, respondents estimated how long could their enterprise's current cash flow maintain its operation, see Table 3. 
Table 3.

How long can enterprise's current cash flow maintain its operation

\begin{tabular}{lcccc}
\hline & Frequency & Percent & Valid Percent & Cumulative Percent \\
\hline Less than 1 month & 6 & 5,7 & 5,7 & 5,7 \\
$1-3$ months & 62 & 59,0 & 59,0 & 64,8 \\
$4-5$ months & 23 & 21,9 & 21,9 & 86,7 \\
6 months or more & 14 & 13,3 & 13,3 & 100,0 \\
Total & 105 & 100 & 100 & \\
\hline
\end{tabular}

Source. author's calculation

The factors with the highest frequency and highest valid percent were considered as the most significant: 1-3 months (frequency 62, valid percent 59,0); 4-5 month (frequency 23, valid percent 21,9). Cumulatively, $80,9 \%$ of the respondents stated that their current cash flow could maintain their enterprise's operations between 1 and 5 moths, see Table 3. Additionally, a twosided $\mathrm{F}$ test $(\mathrm{p}=0,000)$ demonstrated the above statements to be statistically significant and appear equally important.

Given the importance of cash flow for the enterprises' operations, respondents also answered which main means they were considering to deal with the cash flow shortage, see Table 4.

Table 4.

Main means to deal with the cash flow shortage

\begin{tabular}{|c|c|c|c|c|}
\hline & Frequency & Percent & $\begin{array}{c}\text { Valid } \\
\text { Percent }\end{array}$ & $\begin{array}{l}\text { Cumulative } \\
\text { Percent }\end{array}$ \\
\hline $\begin{array}{l}\text { Equity financing (adding new shareholders or capital } \\
\text { increase of former shareholders) }\end{array}$ & 6 & 5,7 & 5,7 & 5,7 \\
\hline $\begin{array}{l}\text { Equity financing (adding new shareholders or capital } \\
\text { increase of former shareholders); Reduction of operating } \\
\text { costs (e.g. layoffs and salary reductions) }\end{array}$ & 15 & 14,3 & 14,3 & 20 \\
\hline $\begin{array}{l}\text { Loans by microfinance companies or private individuals; } \\
\text { Other }\end{array}$ & 1 & 1 & 1 & 21 \\
\hline Loans by commercial banks & 7 & 6,6 & 6,6 & 27,6 \\
\hline Other & 4 & 3,8 & 3,8 & 31,4 \\
\hline No cash flow shortfalls problem & 18 & 17,1 & 17,1 & 48,5 \\
\hline Loans by microfinance companies or private individuals & 3 & 2,9 & 2,9 & 51,4 \\
\hline $\begin{array}{l}\text { Reduction of operating costs (e.g. layoffs and salary } \\
\text { reductions) }\end{array}$ & 27 & 25,7 & 25,7 & 77,1 \\
\hline Loans by commercial banks; Other & 3 & 2,9 & 2,9 & 80 \\
\hline $\begin{array}{l}\text { Loans by commercial banks; Loans by microfinance } \\
\text { companies or private individuals }\end{array}$ & 2 & 1,9 & 1,9 & 81,9 \\
\hline $\begin{array}{l}\text { Loans by commercial banks; Equity financing (adding new } \\
\text { shareholders or capital increase of former shareholders) }\end{array}$ & 6 & 5,7 & 5,7 & 87,6 \\
\hline $\begin{array}{l}\text { Reduction of operating costs (e.g. layoffs and salary } \\
\text { reductions); Other }\end{array}$ & 3 & 2,9 & 2,9 & 90,5 \\
\hline $\begin{array}{l}\text { Equity financing (adding new shareholders or capital increase of } \\
\text { former shareholders); No cash flow shortfalls problem }\end{array}$ & 5 & 4,7 & 4,7 & 9,2 \\
\hline $\begin{array}{l}\text { Reduction of operating costs (e.g. layoffs and salary } \\
\text { reductions); No cash flow shortfalls problem }\end{array}$ & 3 & 2,9 & 2,9 & 98,1 \\
\hline $\begin{array}{l}\text { Loans by microfinance companies or private individuals; } \\
\text { Reduction of operating costs (e.g. layoffs and salary } \\
\text { reductions) }\end{array}$ & 2 & 1,9 & 1,9 & 100,00 \\
\hline Total & 105 & 100 & 100 & \\
\hline
\end{tabular}

Source. author's calculation

The factors with the highest frequency and highest valid percent were considered as the most significant: Reduction of operating costs (e.g. layoffs and salary reductions) (frequency 27, valid percent 25,7); No cash flow shortfalls problem (frequency 18, valid percentage, 17,1); Equity financing (adding new shareholders or capital increase of former shareholders) and 
Reduction of operating costs (e.g. layoffs and salary reductions) (frequency 15, valid percent 14,3). Cumulatively, $57,1 \%$ of the respondents name these main means in dealing with the cash flow shortage. A two-sided $F$ test $(\mathrm{p}=0,000)$ demonstrated the above statements to be statistically significant and appear equally important.

\subsubsection{Fulfilling Contracts}

The principle of "pacta sunt servanda" is considered as one of the fundamental, but also one of the oldest principles of contractual and mandatory law (Oxford Public International Law, 2020). The principle of "pacta sunt servanda" in Croatian legal order has been raised to the rank of the general principle of contract law, so this principle does not bind only the parties to the contract, but each party to any type of contract. Pursuant to Article 9 of the Law on Obligations (2005), a participant in an obligatory relationship is obliged to fulfill the obligation and is responsible for its fulfillment. Entrepreneurs in the terms of business conditions due to restrictions caused by the COVID-19 epidemic face difficulties contracting. For this study, respondents answered what were the main means they were considering to deal with difficulties in fulfilling contracts, see Table 5.

Table 5 .

Main means to deal with difficulties in fulfilling contracts

\begin{tabular}{|c|c|c|c|c|}
\hline & Frequency & Percent & $\begin{array}{c}\text { Valid } \\
\text { Percent }\end{array}$ & $\begin{array}{l}\text { Cumulative } \\
\text { Percent }\end{array}$ \\
\hline Settlement by mutual agreement & 26 & 24,7 & 24,7 & 24,7 \\
\hline $\begin{array}{l}\text { Settlement by mutual agreement; Payment of } \\
\text { liquidated damages }\end{array}$ & 9 & 8,5 & 8,5 & 33,2 \\
\hline No contractual performance issues & 47 & 44,7 & 44,7 & 77,9 \\
\hline Other & 3 & 2,9 & 2,9 & 80,8 \\
\hline $\begin{array}{l}\text { Settlement by mutual agreement; Expect the } \\
\text { government to coordinate and provide clear } \\
\text { disclaimer agreements }\end{array}$ & 3 & 2,9 & 2,9 & 83,7 \\
\hline $\begin{array}{l}\text { Expect the government to coordinate and provide } \\
\text { clear disclaimer agreements; No contractual } \\
\text { performance issues }\end{array}$ & 1 & 1,0 & 1,0 & 84,7 \\
\hline $\begin{array}{l}\text { Expect the government to coordinate and provide } \\
\text { clear disclaimer agreements; Other }\end{array}$ & 1 & 1,0 & 1,0 & 85,7 \\
\hline Settlement by mutual agreement; Other & 2 & 1,9 & 1,9 & 87,6 \\
\hline $\begin{array}{l}\text { Settlement by mutual agreement; Legal or arbitral } \\
\text { settlement }\end{array}$ & 2 & 1,9 & 1,9 & 89,5 \\
\hline $\begin{array}{l}\text { Legal or arbitral settlement; Payment of liquidated } \\
\text { damages }\end{array}$ & 1 & 1,0 & 1,0 & 90,5 \\
\hline $\begin{array}{l}\text { Settlement by mutual agreement; No contractual } \\
\text { performance issues }\end{array}$ & 9 & 8,5 & 8,5 & 99,0 \\
\hline Legal or arbitral settlement & 1 & 1,0 & 1,0 & 100,0 \\
\hline Total & 105 & 100 & 100 & \\
\hline
\end{tabular}

Source. author's calculation

The factors with the highest frequency and highest valid percent were considered as the most significant: No contractual performance issues (frequency 47, valid percent 44,7); Settlement by mutual agreement (frequency 26 , valid percent 24,7 ); Settlement by mutual agreement and Payment of liquidated damages (frequency 9, valid percent 8,5); Settlement by mutual agreement and No contractual performance issues (frequency 9, valid percent 8,5). Cumulatively, $86,4 \%$ of the respondents name these main means in dealing with difficulties in fulfilling contracts. Additionally, two-sided F test $(\mathrm{p}=0,000)$ demonstrated the above statements to be statistically significant and appear equally important. 


\subsubsection{Relief Measures}

Due to the impact of COVID-19 epidemic, governments at all levels and financial institutions announced relief measures to help the economy. Respondents in this study answered which policy they believed was the most effective for their enterprises, see Table 6 .

Table 6.

The most effective relief measures by the Government

\begin{tabular}{|c|c|c|c|c|}
\hline & Frequency & Percent & $\begin{array}{c}\text { Valid } \\
\text { Percent }\end{array}$ & $\begin{array}{c}\text { Cumulative } \\
\text { Percent }\end{array}$ \\
\hline $\begin{array}{l}\text { Reduction of tax rates, reduction or deferral of taxes; } \\
\text { Payment of the minimum wage and salary supplements }\end{array}$ & 28 & 26,7 & 26,7 & 26,7 \\
\hline $\begin{array}{l}\text { Reduce rent for small and medium-sized enterprises and } \\
\text { lower costs for electricity, gas, logistics, etc.; Payment } \\
\text { of the minimum wage and salary supplements }\end{array}$ & 10 & 9,5 & 9,5 & 36,2 \\
\hline $\begin{array}{l}\text { Reduce rent for small and medium-sized enterprises and } \\
\text { lower costs for electricity, gas, logistics, etc.; Reduction } \\
\text { of tax rates, reduction or deferral of taxes }\end{array}$ & 8 & 7,6 & 7,6 & 43,8 \\
\hline $\begin{array}{l}\text { Reduce rent for small and medium-sized enterprises and } \\
\text { lower costs for electricity, gas, logistics, etc. }\end{array}$ & 1 & 1,0 & 1,0 & 44,8 \\
\hline Other & 2 & 1,9 & 1,9 & 46,7 \\
\hline $\begin{array}{l}\text { Reduction of financing costs for SMEs, extension of loan } \\
\text { terms or partial debt relief; Payment of the minimum } \\
\text { wage and salary supplements }\end{array}$ & 9 & 8,6 & 8,6 & 55,2 \\
\hline $\begin{array}{l}\text { Temporary reduction of social insurance premiums and } \\
\text { reimbursement of unemployment insurance to } \\
\text { enterprises that do not lay off staff }\end{array}$ & 6 & 5,7 & 5,7 & 61,0 \\
\hline Reduction of tax rates, reduction or deferral of taxes; & & & & \\
\hline $\begin{array}{l}\text { Reduction of financing costs for SMEs, extension of } \\
\text { loan terms or partial debt relief }\end{array}$ & 15 & 14,3 & 14,3 & 75,2 \\
\hline Reduction of tax rates, reduction or deferral of taxes & 6 & 5,7 & 5,7 & 81,0 \\
\hline Payment of the minimum wage and salary supplements & 13 & 12,4 & 12,4 & 93,3 \\
\hline $\begin{array}{l}\text { Payment of the minimum wage and salary supplements; } \\
\text { Optimization of exporting tax rebate services }\end{array}$ & 1 & 1,0 & 1,0 & 94,3 \\
\hline $\begin{array}{l}\text { Reduction of financing costs for SMEs, extension of loan } \\
\text { terms or partial debt relief }\end{array}$ & 2 & 1,9 & 1,9 & 96,2 \\
\hline $\begin{array}{l}\text { Payment of the minimum wage and salary supplements; } \\
\text { Other }\end{array}$ & 2 & 1,9 & 1,9 & 98,1 \\
\hline $\begin{array}{l}\text { Reduce rent for small and medium-sized enterprises and } \\
\text { lower costs for electricity, gas, logistics, etc.; Provide } \\
\text { fast-track "force majeure" certification to avoid contract } \\
\text { breaches }\end{array}$ & 2 & 1,9 & 1,9 & 100 \\
\hline Total & 105 & 100 & 100 & \\
\hline
\end{tabular}

Source. author's calculation

The factors with the highest frequency and highest valid percent were considered as the most significant: Reduction of tax rates, reduction or deferral of taxes and Payment of the minimum wage and salary supplements (frequency 28, valid percent 26,7); Reduction of tax rates, reduction or deferral of taxes and Reduction of financing costs for SMEs, extension of loan terms or partial debt relief (frequency, 15, valid percent 14,3); Payment of the minimum wage and salary supplements (frequency 13, valid percent 12,4); Reduce rent for small and mediumsized enterprises and lower costs for electricity, gas, logistics, etc. and Payment of the minimum wage and salary supplements (frequency 19, valid percent 9,5); Cumulatively, 62,9\% of the respondents name these measures as the most effective relief measures due to COVID19 epidemic. A two-sided $\mathrm{F}$ test $(\mathrm{p}=0,005)$ demonstrated the above statements to be statistically significant and appear equally important. 


\subsubsection{Total Revenue Expectations}

The COVID-19 epidemic also affected the total revenue expectations. Respondents in this study expressed their expectations of total revenues of their enterprises in 2020 compared to 2019, see Table 7.

Table 7.

Total revenue expectations in 2020 compared to 2019

\begin{tabular}{lcccc}
\hline & Frequency & Percent & Valid Percent & Cumulative Percent \\
\hline Increase by more than 10\% & 3 & 2,9 & 2,9 & 2,9 \\
Increase, but less than or equal to & 1 & 1,0 & 1,0 & 3,8 \\
$\quad$ 10\% & 9 & 8,6 & 8,6 & 12,4 \\
Same as last year & 23 & 21,9 & 21,9 & 34,3 \\
Decrease of less than or equal to & 60 & 57,1 & 57,1 & 91,4 \\
$\quad 10 \%$ & 9 & 8,6 & 8,6 & 100,0 \\
Decrease of more than 10\% & 105 & 100 & 100 & \\
Unable to judge & & & & \\
Total & &
\end{tabular}

Source. author's calculation

The factors with the highest frequency and highest valid percent were considered as the most significant: Decrease of more than 10\% (frequency 60, valid percent 57,1); Decrease of less than or equal to $10 \%$ (frequency 23 , valid percent 21,9 ). Cumulatively, $79 \%$ of the respondents expected that total revenue their companies would gain in 2020, compared to 2019, would decrease by less than or equal to $10 \%$ or more than $10 \%$. A two-sided $\mathrm{F}$ test $(\mathrm{p}=0,005)$ demonstrated the above statements to be statistically significant and appear equally important.

\subsubsection{Change Management}

The insecurity COVID-19 epidemic brings to business requires companies to recognize the need for change, to introduce it quickly, and to adapt to change to be able to implement new ways of doing and sustain business. Change management is thus one of the most important steps in minimizing the COVID-19 impact on people and business operations. Table 8 shows respondents' agreement with the statement: "In a crisis caused by a COVID-19 epidemic it is very important that your company plans short-term business improvements (quick wins)“.

Table 8.

Importance of planning quick wins

\begin{tabular}{lcccc}
\hline & Frequency & Percent & Valid Percent & Cumulative Percent \\
\hline Strongly agree & 24 & 22,9 & 22,9 & 22,9 \\
Agree & 56 & 53,2 & 53,2 & 76,1 \\
I neither agree nor disagree & 23 & 21,9 & 21,9 & 98 \\
Disagree & 1 & 1 & 1 & 99 \\
Strongly disagree & 1 & 1 & 1 & 100 \\
Total & 105 & 100 & 100 & \\
\hline
\end{tabular}

Source: author's calculation

The factors with the highest frequency and highest valid percent were considered as the most significant: Agree (frequency 56, valid percent 53,2); Strongly agree (frequency 24, valid percent 22,9); I neither agree nor disagree (frequency 23, valid percent 21,9). A two-sided $F$ test $(\mathrm{p}<0,000)$ demonstrated the above statements to be statistically significant and appear equally important.

Table 9. shows respondents' agreement with the statement: "Change management is important for your business in a crisis caused by COVID-19 epidemic". 
Table 9.

Change management importance for business in COVID-19 epidemic crisis

\begin{tabular}{lcccc}
\hline & Frequency & Percent & Valid Percent & Cumulative Percent \\
\hline Strongly agree & 34 & 32,4 & 32,4 & 32,4 \\
Agree & 39 & 37,1 & 37,1 & 69,5 \\
I neither agree nor disagree & 24 & 22,9 & 22,9 & 92,4 \\
Disagree & 6 & 5,7 & 5,7 & 98,1 \\
Strongly disagree & 2 & 1,9 & 1,9 & 100 \\
Total & 105 & 100 & 100 & \\
\hline
\end{tabular}

Source. author's calculation

The factors with the highest frequency and highest valid percent were considered as the most significant: Agree (frequency 39, valid percent 37,1); Strongly agree (frequency 39, valid percent 37,1); I neither agree nor disagree (frequency 24, valid percent 22,9). A two-sided F test $(\mathrm{p}<0,000)$ demonstrated the above statements to be statistically significant and appear equally important.

Table 10. shows respondents' agreement with the statement: "Change management is important for your company's recovery after a crisis caused by COVID-19 epidemic“.

Table 10 .

Change management importance for company's recovery after COVID-19 epidemic crisis

\begin{tabular}{lcccc}
\hline & Frequency & Percent & Valid Percent & Cumulative Percent \\
\hline Strongly agree & 41 & 39 & 39 & 39 \\
Agree & 48 & 45,7 & 45,7 & 84,7 \\
I neither agree nor disagree & 13 & 12,4 & 12,4 & 97,1 \\
Disagree & 2 & 1,9 & 1,9 & 99 \\
Strongly disagree & 1 & 1 & 1 & 100 \\
Total & 105 & 100 & 100 & \\
\hline
\end{tabular}

Source. author's calculation

The factors with the highest frequency and highest valid percent were considered as the most significant: Agree (frequency 48, valid percent 45,7); Strongly agree (frequency 41, valid percent 39; I neither agree nor disagree (frequency 13, valid percent 12,4). A two-sided F test $(\mathrm{p}<0,000)$ demonstrated the above statements to be statistically significant and appear equally important.

\section{Conclusion}

SARS-CoV-2 is the latest virus in the coronavirus family and the causative pathogen of the disease COVID-19 which has spread all around the world, including Croatia. To localize the spread of the virus, the Government of the Republic of Croatia declared a lockdown on March 16,2020 , which affected all sectors and industries in the Croatian economy. To reduce the negative consequences due to the COVID-19 epidemic, the Government presented relief measures to help the economy immediately after the lockdown was declared. These measures are the culmination of recognition and quick response to problems that arise in new business conditions so that is why it is necessary to identify the financial and other problems that entrepreneurs face during the epidemic. According to the results of this study, staff wages and social security charges, payment of invoices and rent are among the most common financial problems during the lockdown, while other business problems mostly include reduction of orders, disruption of logistics, increased difficulty of financing and inability to deliver existing orders. All these factors are very important indicators in the creation and implementation of policies to reduce the impact of the epidemic on SMEs, the most vulnerable part of the economy. 
Lack of money is one of the most important reasons why SMEs fail to survive on the market. In the context of this crisis, it is important to pay attention to the time in which enterprises can operate with the current cash flow. The results of this study show that $80,9 \%$ respondents can operate with the existing cash flow in a period of 1 to 5 months. In the same time, entrepreneurs who took part in this study see the solution of cash flow shortage mostly in the reduction of operating costs and the equity financing by adding new shareholders or capital increase of former shareholders. Fulfillment of contractual obligations is also one of the most important steps in business and the important indicator in creating the relief measures in this area. According to results of this study, 24,7\% respondents are ready to solve these problems by the settlement by mutual agreement. This indicates how the chosen direction bypasses the courts and other institutions and speaks in favor of mutual trust and respect of the contracting parties and is an important indicator in the rapid response to the problems that could be brought by the COVID-19 epidemic in this business segment.

Immediately after the lockdown was declared, the Government of the Republic of Croatia announced relief measures for SMEs. Among the presented measures, 26,7\% of respondents in this study rated reduction of tax rates, reduction or deferral of taxes and payment of minimum wage and salary supplements as the most effective measures. Also, the reduction of financing costs for SMEs, extension of loan terms or partial debt relief are named among the most effective relief measures. These can be very important indicators for the Government in quick and efficient response to SMEs' needs, even more because $79 \%$ of respondents expect their total revenue to decrease in 2020 , compared to 2019 , by $10 \%$ or more.

Finally, change management is one of the most important segments in management and business in general. According to this study, Croatian entrepreneurs see change management as an important step in responding to the crisis caused by the COVID-19 epidemic. This can be an important indicator to include change management principles, methods and tools in economic relief measures and implement changes more efficient in business operations of SMEs in Croatia. Change management is certainly crucial for SMEs and their future when COVID-19 crisis is over.

Results of this study show that Croatian SMEs are aware of the problems due to the crisis caused by the COVID-19 epidemic. Croatian entrepreneurs are ready to respond to challenges and problems by implementing effective relief measures adopted by the Government during and after the crisis to save and strengthen their business. Change management also has a very important role in these measures and for each enterprise. Change management principles and tools should be included in every relief measure in order for SMEs to successfully adapt to these new business conditions. Relief measures, based on SMEs needs and change management principles, could be also implemented on a global level to protect, and strengthen SMEs and the most important segment of the global economy. Also, the limitations of this study, which are reflected in the small number of respondents willing to participate in the study and the fact that the study was conducted only during the lockdown period, and not during the entire period in which special epidemiological measures were applied, which has a direct effect on SMEs economic activity, should be considered.

\section{Acknowledgement}

This paper was presented at the 2nd International Conference on Research in Management, February 19-21, 2021, Vienna, Austria 


\section{References}

Bobdey, S., and Ray, S., (2020). Going viral-Covid-19 impact assessment: a perspective beyond clinical practice. J Mar Med Soc.; 22(1):9. https://doi.org/10.4103/jmms.jmms -12_20

European Commission (2003). Recommendation 2003/361/EC: SME Definition [Online]. Available: https://eur-lex.europa.eu/LexUriServ/LexUriServ.do?uri=OJ:L:2003:124:0036: 0041:en:PDF

OECD (2019). OECD SME and Entrepreneurship Outlook 2019, OECD Publishing, Paris [Online]. Available: https://doi.org/10.1787/34907e9c-en

Fernandes, N. (March 2020). Economic Effects of Coronavirus Outbreak (COVID-19) on the World Economy [Online]. Available: http://dx.doi.org/10.2139/ssrn.3557504

Ateson, A. (2020). What Will Be the Economic Impact of COVID-19 in the US? Rough Estimates of Disease Scenarios. NBER Working Paper No. 26867. https://doi.org/ $\underline{10.3386 / \mathrm{w} 26867}$

McKibin, W. and Fernando, R. (2020). The economic impact of COVID-19. Economics in the time of COVID-19, London: Centre for Economic Policy Research, pp.45-51.

Baldwin, R. and Tomiura, E. (2020). Thining ahead about the trade impact of COVID-19. Economics in time of COVID-19, London: Centra for Economic Policy Research, pp. 5971.

García-Cabrera, A.M. and García-Barba Hernández, F., (2012). Resistance to Change of Employees: An Analysis of the Thought-Feeling-Action Sequence. International Journal of the Academy of Organizational Behavior Management, 2(2), pp. 1-34.

Oxford Public International Law (2020). Pacta Sunt Servanda [Online]). Available: https://opil.ouplaw.com/view/10.1093/law:epil/9780199231690/law-9780199231690$\underline{\mathrm{e} 1449}$

Official Gazette of the Republic of Croatia "Narodne novine", Law on Obligations (2005) [Online]. Available: https://narodne-novine.nn.hr/clanci/sluzbeni/2005_03_35_707.html 